Part of Journal of Research of the National Bureau of Standards, Volume 14, March 1935

\title{
OPTICAL ROTATIONS AND OTHER PROPERTIES OF THE LEAD AND CALCIUM ALDONATES ${ }^{1}$
}

\author{
By Horace S. Isbell
}

\section{ABSTRACT}

The preparation and properties of numerous lead and calcium salts of the aldonic acids are reported. It is shown that the addition of lead salts to the alkaline earth salts of the $\alpha$-hydroxy acids causes large changes in specific rotation, which follow with striking regularity the configuration of the $\alpha$-carbon atom in the aldonic acid. Evidence is presented to show that the lead aldonates are acids which can be titrated with standard alkali and that their solutions give rise by hydrolysis to small quantities of the free aldonic acids which undergo lactone formation, causing small changes in rotation.

\section{CONTENTS}

I. Optical rotations of the lead and calcium aldonates

II. Acidic properties of the lead aldonates

III. Hydrolysis of the lead aldonates and the formation of lactones

IV. Experimental procedure __ _

1. Addition of lead nitrate to calcium gluconate $\ldots \ldots 312$

2. Titration of lead gluconate with barium hydroxide $\ldots \ldots . .$.

3. Mutarotation of the lead aldonates and the effect of heat treatment

4. Lead gluconate, $\mathrm{Pb}\left(\mathrm{C}_{6} \mathrm{H}_{11} \mathrm{O}_{7}\right)_{2}$

5. Lead xylonate, $\mathrm{Pb}\left(\mathrm{C}_{5} \mathrm{H}_{9} \mathrm{O}_{6}\right)_{2} \cdot \mathrm{H}_{2} \mathrm{O} \ldots \ldots 313$

6. Lead galactonate, $\mathrm{Pb}\left(\mathrm{C}_{6} \mathrm{H}_{11} \mathrm{O}_{7}\right)_{2 \ldots} \ldots 14$

7. Lead arabonate, $\mathrm{Pb}\left(\mathrm{C}_{5} \mathrm{H}_{9} \mathrm{O}_{6}\right)_{2 \ldots} \ldots \ldots 314$

8. Lead mannonate, $\mathrm{Pb}\left(\mathrm{C}_{6} \mathrm{H}_{11} \mathrm{O}_{7}\right)_{2 \ldots} \ldots \ldots \ldots \ldots$

9. Calcium xylonate, $\mathrm{Ca}\left(\mathrm{C}_{5} \mathrm{H}_{9} \mathrm{O}_{6}\right)_{2} \cdot 2 \mathrm{H}_{2} \mathrm{O}_{\ldots} \ldots$

10. Calcium $\alpha$-glucoheptonate, $\mathrm{Ca}\left(\mathrm{C}_{7} \mathrm{H}_{13} \mathrm{O}_{8}\right)_{2} \cdot 3 \mathrm{H}_{2} \mathrm{O}_{\ldots} \ldots$

\section{OPTICAL ROTATIONS OF THE LEAD AND CALCIUM ALDONATES}

A comparison of the specific rotations of the salts of gluconic acid ${ }^{2}$ shows that the lead and nickel salts are levorotatory, while the sodium, potassium, ammonium, barium, calcium, magnesium, manganese, and zinc salts are dextrorotatory. This suggests that the lead and nickel salts differ fundamentally from the others. On account of this it was decided to investigate other sugar acids in order to determine whether their lead salts also exhibit unusual properties. Some preliminary experiments given in table 1 showed that the addition of lead nitrate to a solution of calcium gluconate caused the optical rotation to change, before readings could be made, from a dextrorotatory to a levorotatory value. This change is in the opposite direc-

${ }^{1}$ A part of the work given in this paper was presented by H. S. Isbell and F. J. Bates before the Division of Sugar Chemistry, American Chemical Society, St. Petersburg, Fla., March 1934.

${ }_{2}$ May, Weisberg, and Herrick. J. Wash. Acad. Sci., 19, 445 (1929). 
tion from that which occurs when ammonium molybdate or uranate is added to calcium gluconate, ${ }^{3}$ but it is what might be expected from the optical rotation of lead gluconate. As may be seen from figure 1, the optical rotation varies with the concentration. The molecular rotation of 0.05 molar calcium gluconate containing 0.05 molar lead nitrate is $-2,200$, whereas the molecular rotation of 0.05 molar lead gluconate is $-3,200$ and of calcium gluconate $+4,200$. In other words, the optical rotation of the solution containing equivalent quantities of lead and calcium approaches the rotation of the lead salt, which is evidence that lead gluconate predominates. Presumably the lead ion combines in some manner with the hydroxyl groups of the sugar acid so as to form a complex molecule or ion. The aldonic acids contain several hydroxyl groups which could enter into the formation of complex molecules. The configuration of the lead complex and its optical rotation depend on whether the

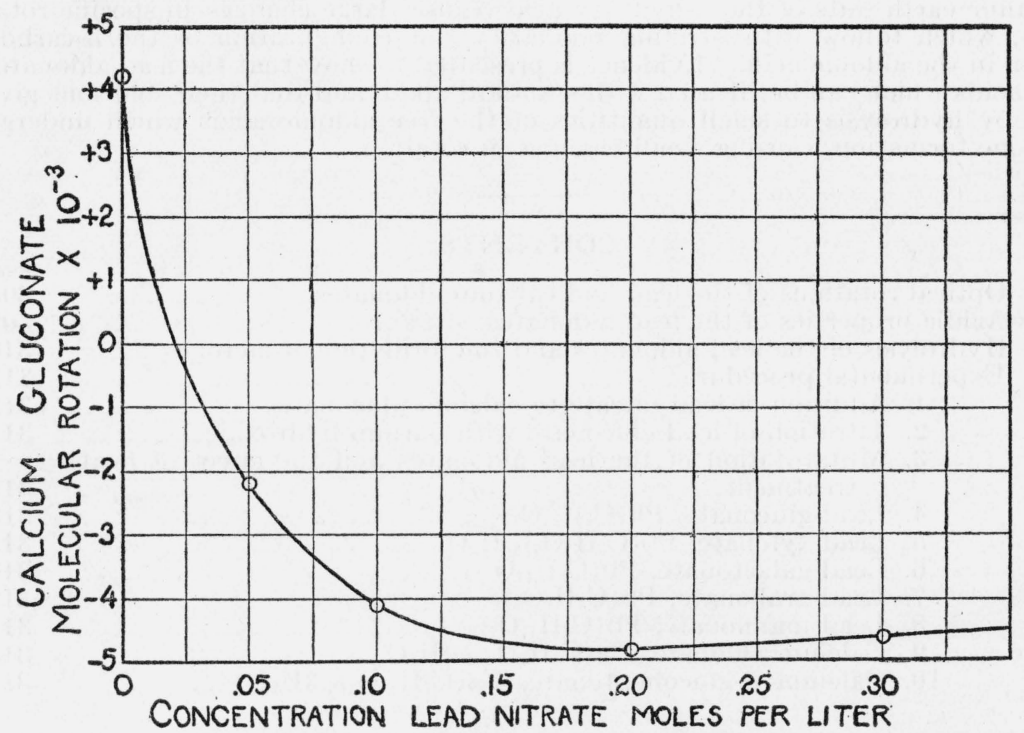

FIGURE 1.-Changes in optical rotation caused by adding lead nitrate to 0.05 molar calcium gluconate.

hydroxyl forming the complexion lies to the right or left. Although various metals form complex ions which differ in structure and optical rotation, for a given metal one would expect a correlation between the optical rotation of the complex ion and the configuration of the hydroxyl group involved in its formation.

A comparison of the crystalline lead and calcium salts of the aldonic acids, as given in table 2 , reveals a striking regularity between the difference in the optical rotations and the configuration of the $\alpha$-carbon. The calcium salts of the aldonic acids are more dextrorotatory than the lead when the hydroxyl group of the $\alpha$-carbon

\footnotetext{
${ }^{3}$ Bennet-Clark. Biochem. J. 28, 45 (1934); also Fisher and Bailey, J. Ass'n. Official Agr. Chem. 15,
} 461 (1932). 
lies to the right, and more levorotatory when it lies to the left. As only a limited number of crystalline lead salts are available for comparison, it is necessary to obtain additional data in order to substantiate this empirical rule.

TABLE 1.-Changes in the rotation of calcium gluconate caused by the addition of lead nitrate

\begin{tabular}{|c|c|c|}
\hline \multirow{4}{*}{ Elapsed time } & \multicolumn{2}{|c|}{$\begin{array}{l}\text { Rotation of calcium } \\
\text { gluconate }\end{array}$} \\
\hline & $+3.11^{\circ} \mathrm{S}$ & $+3.11^{\circ} \mathrm{S}$ \\
\hline & \multicolumn{2}{|c|}{$\begin{array}{c}\text { Rotation after addi- } \\
\text { tion of }-\end{array}$} \\
\hline & $\begin{array}{l}2 \mathrm{~g} \text { of lead } \\
\text { nitrate in } \\
100 \mathrm{ml} \text { of } \\
\text { solution }\end{array}$ & $\begin{array}{l}6 \mathrm{~g} \text { of lead } \\
\text { nitrate in } \\
100 \mathrm{ml} \text { of } \\
\text { solution }\end{array}$ \\
\hline $\begin{array}{l}5 \text { minutes } \\
15 \text { minutes } \\
30 \text { minutes } \\
60 \text { minutes....... }\end{array}$ & $\begin{array}{l}{ }^{\circ} \mathrm{S} \\
-1.30 \\
-1.28 \\
-1.22 \\
-1,21\end{array}$ & $\begin{array}{l}{ }^{\circ} \mathrm{S} \\
-3.58 \\
-3.53 \\
-3.52 \\
-3.50\end{array}$ \\
\hline
\end{tabular}

TABLE 2.-Comparison of the optical rotations of aqueous lead and calcium salts at $20^{\circ} \mathrm{C}$

\begin{tabular}{|c|c|c|c|c|c|c|}
\hline Substance & Formula & $\begin{array}{c}\text { Con- } \\
\text { centra- } \\
\text { tion } \\
(\mathrm{g} / 100 \\
\mathrm{ml})\end{array}$ & {$[\alpha]_{D}^{20}$} & $\begin{array}{l}\text { Molecu- } \\
\text { lar rota- } \\
\text { tion }{ }^{1}\end{array}$ & $\begin{array}{l}\text { Differ- } \\
\text { ence in } \\
\text { molecu- } \\
\text { lar rota- } \\
\quad \text { tion }\end{array}$ & $\begin{array}{l}\text { Con- } \\
\text { figura- } \\
\text { tion? }\end{array}$ \\
\hline $\begin{array}{l}\text { Calcium gluconate. } \\
\text { Lead gluconate }\end{array}$ & $\begin{array}{l}\mathrm{Ca}\left(\mathrm{C}_{6} \mathrm{H}_{11} \mathrm{O}_{7}\right)_{2} \cdot 2 \mathrm{H}_{2} \mathrm{O} \\
\mathrm{Pb}\left(\mathrm{C}_{6} \mathrm{H}_{11} \mathrm{O}_{7}\right)_{2} \ldots\end{array}$ & $\begin{array}{l}\text { 2. } 33 \\
\text { 3. } 12\end{array}$ & $\begin{array}{l}+8.80 \\
-5.23\end{array}$ & $\begin{array}{l}+4,100 \\
-3,120\end{array}$ & \}$+7,220$ & + \\
\hline $\begin{array}{l}\text { Calcium mannonate. } \\
\text { Lead mannonate.... }\end{array}$ & $\begin{array}{l}\mathrm{Ca}\left(\mathrm{C}_{6} \mathrm{H}_{11} \mathrm{O}_{7}\right)_{2} .2 \mathrm{H}_{2} \mathrm{O} \\
\mathrm{Pb}\left(\mathrm{C}_{6} \mathrm{H}_{11} \mathrm{O}_{7}\right)_{2} \ldots\end{array}$ & $\begin{array}{l}2.33 \\
2.99\end{array}$ & $\begin{array}{l}-7.31 \\
-5.50\end{array}$ & $\begin{array}{l}-3,410 \\
-3,290\end{array}$ & -120 & - \\
\hline $\begin{array}{l}\text { Calcium galactonate } \\
\text { Lead galactonate }\end{array}$ & $\begin{array}{l}\mathrm{Ca}\left(\mathrm{C}_{6} \mathrm{H}_{11} \mathrm{O}_{7}\right)_{2} .5 \mathrm{H}_{2} \mathrm{O} \\
\mathrm{Pb}\left(\mathrm{C}_{6} \mathrm{H}_{11} \mathrm{O}_{7}\right)_{2} \ldots\end{array}$ & $\begin{array}{l}2.56 \\
.416\end{array}$ & $\begin{array}{r}+.93 \\
-12.90\end{array}$ & $\begin{array}{r}+480 \\
-7,710\end{array}$ & \}$+8,190$ & + \\
\hline $\begin{array}{l}\text { Calcium xylonate.. } \\
\text { Lead xylonate..... }\end{array}$ & $\begin{array}{l}\mathrm{Ca}\left(\mathrm{C}_{5} \mathrm{H}_{9} \mathrm{O}_{6}\right)_{2} \cdot 2 \mathrm{H}_{2} \mathrm{O} \\
\mathrm{Pb}\left(\mathrm{C}_{5} \mathrm{H}_{9} \mathrm{O}_{6}\right)_{2} \mathrm{H}_{2} \mathrm{O} \ldots\end{array}$ & $\begin{array}{l}\text { 2. } 03 \\
1.71\end{array}$ & $\begin{array}{r}+12.42 \\
-6.50\end{array}$ & $\begin{array}{l}+5,050 \\
-3,610\end{array}$ & \}$+8,660$ & + \\
\hline $\begin{array}{l}\text { Calcium arabonate. } \\
\text { Lead arabonate. }\end{array}$ & $\begin{array}{l}\mathrm{Ca}\left(\mathrm{C}_{5} \mathrm{H}_{9} \mathrm{O}_{6}\right)_{2} .5 \mathrm{H}_{2} \mathrm{O}_{\ldots} \\
\mathrm{Pb}\left(\mathrm{C}_{5} \mathrm{H}_{9} \mathrm{O}_{6}\right)_{2} \ldots\end{array}$ & $\begin{array}{l}2.30 \\
.169\end{array}$ & $\begin{array}{l}+2.97 \\
-6.70\end{array}$ & $\begin{array}{l}+1,340 \\
-3,600\end{array}$ & \}$+4,940$ & + \\
\hline
\end{tabular}

1 The product of the specific rotation and the molecular weight of the salt.

2 When the hydroxyl on the $\alpha$-carbon lies to the right the configuration is designated with a plus sign. 
TABLE 3.-Change of rotation of salts of aldonic acids caused by addition of $\mathrm{Pb}\left(\mathrm{NO}_{3}\right)_{2}$.

\begin{tabular}{|c|c|c|c|c|c|}
\hline \multirow{3}{*}{ Substance } & \multicolumn{3}{|c|}{$\begin{array}{l}\text { Rotations for aqueous solu- } \\
\text { tions of various composition }\end{array}$} & \multirow{3}{*}[\mathrm{M}]{$-\left[\mathrm{M}^{\prime}\right]$} & \multirow{3}{*}{$\begin{array}{l}\text { Config- } \\
\text { uration }\end{array}$} \\
\hline & \multicolumn{2}{|c|}{$\begin{array}{l}\text { Moles per liter of } \\
\text { aldonate } 0.05\end{array}$} & \multirow{2}{*}{$\begin{array}{c}\text { Moles per } \\
\text { liter of al- } \\
\text { donate } \\
0.05 \text { lead } \\
\text { nitrate } 0.2 \\
{ }^{1}\left[\mathrm{M}^{\prime}\right]\end{array}$} & & \\
\hline & {$[\alpha]_{D}^{20}$} & ${ }^{1}[\mathrm{M}]$ & & & \\
\hline Calcium gluconate, $\mathrm{Ca}\left(\mathrm{C}_{6} \mathrm{H}_{11} \mathrm{O}_{7}\right)_{2} \cdot 2 \mathrm{H}_{2} \mathrm{O}$. & +8.80 & $+4,100$ & $-4,860$ & $+8,960$ & + \\
\hline Magnesium gluconate, $\mathrm{Mg}\left(\mathrm{C}_{6} \mathrm{H}_{11} \mathrm{O}_{7}\right)_{2.3 \mathrm{H}}$ & +11.30 & $+5,290$ & $-5,340$ & $+10,630$ & + \\
\hline Calcium mannonate, $\mathrm{Ca}\left(\mathrm{C}_{6} \mathrm{H}_{11} \mathrm{O}_{7}\right)_{2.2}$ & -7.31 & $-3,410$ & $-1,770$ & $-1,640$ & - \\
\hline Calcium galactonate, $\mathrm{Ca}\left(\mathrm{C}_{6} \mathrm{H}_{11} \mathrm{O}_{7}\right)$ & +.93 & +480 & $-14,230$ & $+14,710$ & + \\
\hline Calcium gulonate, $\mathrm{Ca}\left(\mathrm{C}_{6} \mathrm{H}_{11} \mathrm{O}_{7}\right)_{2 \ldots}$ & +10.87 & $+4,680$ & -400 & $+5,080$ & + \\
\hline Calcium altronate, $\mathrm{Ca}\left(\mathrm{C}_{6} \mathrm{H}_{11} \mathrm{O}_{7}\right)_{2} .3 \mathrm{H}_{2} \mathrm{O}$ & +2.08 & $+1,010$ & $-11,590$ & $+12,600$ & + \\
\hline Calcium allonate (amornhous). & & & $+5,620$ & $-5,700$ & \\
\hline Calcium arabonate, $\mathrm{Ca}\left(\mathrm{C}_{5} \mathrm{H}_{9} \mathrm{O}_{6}\right)_{2} .5 \mathrm{H}_{2} \mathrm{O}$ & +2.97 & $+1,340$ & $-9,540$ & $+10,880$ & + \\
\hline Calcium xylonate, $\mathrm{Ca}\left(\mathrm{C}_{5} \mathrm{H}_{9} \mathrm{O}_{6}\right)_{2} 2 \mathrm{H}_{2} \mathrm{O}$ & +12.42 & $+5,050$ & $-7,720$ & $+12,750$ & + \\
\hline Magnesium xylonate, $\mathrm{Mg}\left(\mathrm{C}_{5} \mathrm{H}_{9} \mathrm{O}_{6}\right)_{2} 3 \mathrm{H}_{2} \mathrm{O}$ & +15.47 & $+6,320$ & $-7,900$ & $+14,220$ & + \\
\hline Calcium $\alpha$-glucoheptonate, $\mathrm{Ca}\left(\mathrm{C}_{7} \mathrm{H}_{13} \mathrm{O}_{8}\right)_{2} .3 \mathrm{H}_{2} \mathrm{O}$ & +5.95 & $+3,240$ & $-5,100$ & $+8,340$ & + \\
\hline Calcium $\beta$-glucoheptonate (amorphous) & -8.95 & $-4,410$ & $+11,510$ & $-15,920$ & - \\
\hline Calcium rhamnonate (amorphous) & +13.46 & $+5,360$ & $+3,360$ & $+2,000$ & + \\
\hline Calcium lactobionate (amorphous) ....... & +27.00 & $+20,370$ & $+18,330$ & $+2,040$ & + \\
\hline
\end{tabular}

1 The specific rotation times the molecular weight of the original salt.

Attention was directed above to the fact that on adding lead nitrate to calcium gluconate the optical rotation approaches that of lead gluconate. Thus it is apparent that intormation may be obtained indirectly by measuring the changes in optical rotation which occur after adding lead nitrate; in this way lead aldonates are formed in solution and measurements can be made, even though the crystalline salts are not known. The results obtained in this manner with salts derived from twelve aldonic acids are given in table 3 . In each case the difference in the optical rotations agrees with the lead-salt rule enunciated above. Since the probability of the occurrence of this regularity without a directing influence is remote, probably the $\alpha$-hydroxyl group is involved, perhaps by giving rise to strongly optically active coordination compounds with lead. The remaining hydroxyl groups and other factors such as ionization, association, and hydrolysis undoubtedly contribute to the changes in rotation and give rise to the variations in the numerical values. The proportions of the complex ions in solution may be small and vary widely, so that the molecular rotations should not be regarded as true molecular rotations but rather as comparable measures of the optical rotations in the equilibrium states. The optical rotations of the alkaline earth salts in which the hydroxyl groups on the alpha and beta carbons lie on opposite sides, with the exception of calcium lactobionate, appear to be affected more by the addition of lead nitrate than those in which the hydroxyl groups lie side by side. The much smaller effect of lead nitrate on the optical rotation of calcium lactobionate is surprising but not inimical. The large lactobionic acid molecule contains a second grouping, the glycosidic and the adjacent hydroxyl, which is capable of coordination with lead ions. On account of this complication the lead salt rule may not apply to all bionic acids. 


\section{ACIDIC PROPERTIES OF THE LEAD ALDONATES}

As may be seen from the $\mathrm{pH}$ titration curve given in figure 2, lead gluconate is a definite acid requiring one equivalent of alkali for neutralization. This might be explained by the following equation:

$2 \mathrm{~Pb}\left(\mathrm{C}_{6} \mathrm{H}_{11} \mathrm{O}_{7}\right)_{2}+\mathrm{Ba}(\mathrm{OH})_{2} \longrightarrow \mathrm{Ba}\left(\mathrm{C}_{6} \mathrm{H}_{11} \mathrm{O}_{7}\right)_{2}+2 \mathrm{PbOH}\left(\mathrm{C}_{6} \mathrm{H}_{11} \mathrm{O}_{7}\right)$.

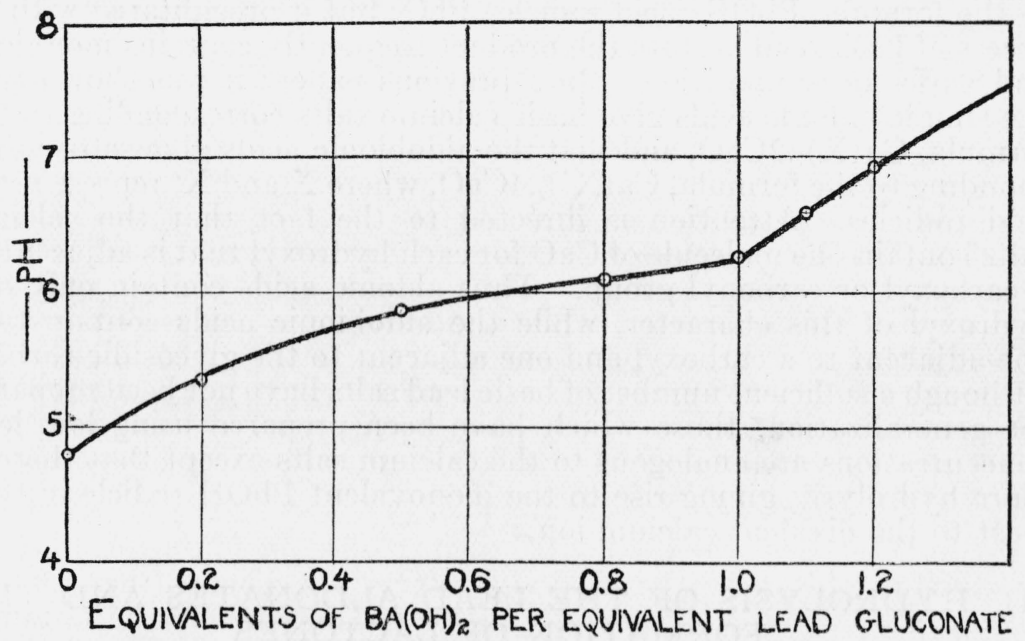

FIgure 2.-N/20 lead gluconate containing barium hydroxide.

Yet the reaction is not as simple as the equation indicates because lead tends to form complex molecules, especially with hydroxy acids. ${ }^{4}$ If the lead were combinea with the carboxyl and hydroxyl groups by means of primary and secondary valence bonds, as given by the formula below, then the hydrogen atoms marked with positive signs might

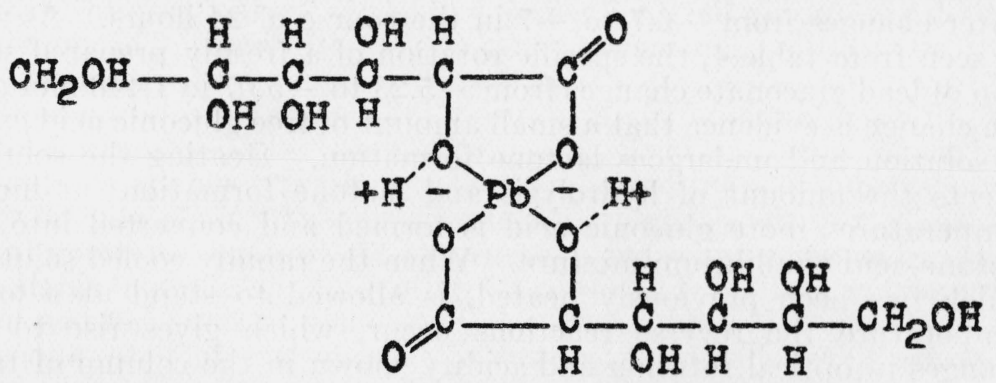

FIGURE 3.-Hypothetical structure of lead gluconate.

be considered as the cations of a substituted plumbous acid. One might expect the acid to require two equivalents of alkali for neutralization, but it is well known that only one ${ }^{5}$ of the two hydrogen atoms in plumbous acid is readily replaced by metals. The plumbous acid structure, while hypothetical, resembles other similar structures, such

4 Jellinck and Gordon. Z. phys. Chem. 112, 207 (1924).

5 Hantzsch. Z. Anorg. Chem. 30, 312 (1902). 
as the imidoauric acids, ${ }^{6}$ and adequately accounts for the marked acidity, in harmony with the chemistry of the hydroxy acids and of lead.

When slightly more than one equivalent of alkali is added to a solution of lead gluconate a difficultly soluble basic salt separates. It appears that sugar acids generally form similar compounds. If prepared in the manner described for basic lead gluconate they correspond to the formula, $\mathrm{PbOH}$ (acid radicle) $\mathrm{PbO}$; but if precipitated with an excess of basic lead acetate the product frequently contains more lead and varies in composition. In a previous paper ${ }^{7}$ it was shown that the simple aldonic acids give basic calcium salts corresponding to the formula, $\mathrm{Ca}(\mathrm{X})_{2} \cdot 2 \mathrm{CaO}$, and that the aldobionic acids give salts corresponding to the formula, $\mathrm{Ca}\left(\mathrm{X}^{\prime}\right)_{2} .4 \mathrm{CaO}$, where $\mathrm{X}$ and $\mathrm{X}^{\prime}$ represent the acid radicles. Attention is directed to the fact that the calcium salts contain one molecule of $\mathrm{CaO}$ for each hydroxyl that is adjacent to a carboxyl or carbonyl group. Thus aldonic acids contain only one hydroxyl of this character, while the aldobionic acids contain two, one adjacent to a carboxyl and one adjacent to the glycosidic carbon. Although a sufficient number of basic lead salts have not been prepared for generalization, those which have been prepared using low lead concentrations are analogous to the calcium salts except that there is more hydrolysis, giving rise to the monovalent $\mathrm{PbOH}$ radicle in contrast to the divalent calcium ion.

\section{HYDROLYSIS OF THE LEAD ALDONATES AND THE FORMATION OF LACTONES}

It may be seen from table 1 that the optical rotation of a reaction mixture containing lead gluconate prepared by adding lead nitrate to a solution of calcium gluconate, exhibits a small but definite mutarotation. Measurements with numerous lead aldonates have revealed that similar changes are given by other lead salts and that they resemble the mutarotations of the sugar acids. As previously shown by Rehorst ${ }^{8}$ the specific rotation of pure gluconic acid dissolved in water changes from -6.7 to +7 in the course of 24 hours. As may be seen from table 4, the specific rotation of a freshly prepared solution of lead gluconate changes from -5.23 to -5.07 in 1,440 minutes; the change is evidence that a small amount of free gluconic acid exists in solution and undergoes lactone formation. Heating the solution affects the amount of hydrolysis and lactone formation; at higher temperatures more gluconic acid is formed and converted into the lactone-acid equilibrium mixture. When the rapidly cooled solution, which has been previously heated, is allowed to stand at a lower temperature the reverse reactions occur, which gives rise to the changes in optical rotation and acidity shown in the column of table 4 marked "heated sample." The changes in the specific rotations and hydrogen ion concentrations of aqueous lead xylonate, mannonate, arabonate, and galactonate, on heating and standing, also agree with what might be anticipated if more hydrolysis and lactone formation occur at higher temperatures. The reactions are complex, in that equilibrium is established with at least the lead salt and the free acid, and between the acid and its $\gamma$ - and $\delta$-lactones. Probably the specific

\footnotetext{
${ }^{6}$ Kharasch and Isbell. J. Am. Chem. Soc. 53, 3059 (1931).

7 BS J. Research 11, 649 (1933) RP613.

8 Ber. Deut. Chem. Ges. 61, 163 (1928)
} 
TABLE 4.-Specific rotations and $\mathrm{pH}$ values of saturated solutions of lead aldonates at $20^{\circ} \mathrm{C}$

\begin{tabular}{|c|c|c|c|c|c|c|c|c|c|c|c|c|c|c|c|c|c|c|c|c|}
\hline \multirow{3}{*}{ Time } & \multicolumn{4}{|c|}{$\begin{array}{l}\text { Lead gluconate } 3.123 \mathrm{~g} \\
\mathrm{~Pb}\left(\mathrm{C}_{6} \mathrm{H}_{11} \mathrm{O}_{7}\right)_{2} \text { per } 100 \mathrm{ml}\end{array}$} & \multicolumn{4}{|c|}{$\begin{array}{l}\text { Lead mannonate } 3.657 \mathrm{~g} \\
\mathrm{~Pb}\left(\mathrm{C}_{6} \mathrm{H}_{11} \mathrm{O}_{7}\right)_{2} \text { per } 100 \mathrm{ml}\end{array}$} & \multicolumn{4}{|c|}{$\begin{array}{l}\text { Lead galactonate } 0.4160 \mathrm{~g} \\
\mathrm{~Pb}\left(\mathrm{C}_{6} \mathrm{H}_{11} \mathrm{O}_{7}\right)_{2} \text { per } 100 \mathrm{ml}\end{array}$} & \multicolumn{4}{|c|}{$\begin{array}{l}\text { Lead arabonate } 0.1689 \mathrm{~g} \\
\mathrm{~Pb}\left(\mathrm{C}_{5} \mathrm{H}_{9} \mathrm{O}_{6}\right)_{2} \text { per } 100 \mathrm{ml}\end{array}$} & \multicolumn{4}{|c|}{$\begin{array}{c}\text { Lead xylonate } 1.706 \mathrm{~g} \\
\mathrm{~Pb}\left(\mathrm{C}_{5} \mathrm{H}_{9} \mathrm{O}_{6}\right)_{2} \mathrm{H}_{2} \mathrm{O} \text { per } 100 \mathrm{ml}\end{array}$} \\
\hline & \multicolumn{2}{|c|}{$\begin{array}{l}\text { Freshly pre- } \\
\text { pared sample }\end{array}$} & \multicolumn{2}{|c|}{ Heated sample } & \multicolumn{2}{|c|}{$\begin{array}{l}\text { Freshly pre- } \\
\text { pared sample }\end{array}$} & \multicolumn{2}{|c|}{ Heated sample } & \multicolumn{2}{|c|}{$\begin{array}{l}\text { Freshly pre- } \\
\text { pared sample }\end{array}$} & \multicolumn{2}{|c|}{ Heated sample } & \multicolumn{2}{|c|}{$\begin{array}{l}\text { Freshly pre- } \\
\text { pared sample }\end{array}$} & \multicolumn{2}{|c|}{ Heated sample } & \multicolumn{2}{|c|}{$\begin{array}{l}\text { Freshly pre- } \\
\text { pared sample }\end{array}$} & \multicolumn{2}{|c|}{ Heated sample } \\
\hline & {$[\alpha]_{D}^{20}$} & $\mathrm{pH}$ & {$[\alpha]_{D}^{20}$} & $\mathrm{pH}$ & {$[\alpha]_{D}^{20}$} & $\mathrm{pH}$ & {$[\alpha]_{D}^{20}$} & $\mathrm{pH}$ & {$[\alpha]_{D}^{20}$} & $\mathrm{pH}$ & {$[\alpha]_{D}^{20}$} & $\mathrm{pH}$ & {$[\alpha]_{D}^{20}$} & $\mathrm{pH}$ & {$[\alpha]_{D}^{20}$} & $\mathrm{pH}$ & {$[\alpha]_{\mathrm{D}}^{20}$} & $\mathrm{pH}$ & {$[\alpha]_{\mathrm{D}}^{20}$} & $\mathrm{pH}$ \\
\hline $\begin{array}{r}\text { Minutes } \\
10 \\
60 \\
120 \\
180 \\
1,440 \\
2,880\end{array}$ & $\begin{array}{l}-5.23 \\
-5.12 \\
-5.18 \\
-5.15 \\
-5.07 \\
-5.05\end{array}$ & $\begin{array}{c}4.65 \\
-4.72\end{array}$ & $\begin{array}{l}-2.81 \\
-3.52 \\
-3.96 \\
-4.20 \\
-4.97 \\
-5.01\end{array}$ & $\begin{array}{c}4.90 \\
4.72\end{array}$ & $\begin{array}{l}-5.93 \\
-5.80 \\
-5.59 \\
-5.55 \\
-5.29 \\
-5.20\end{array}$ & $\begin{array}{c}4.5 \\
5.5\end{array}$ & $\begin{array}{l}-3.25 \\
-3.68 \\
-3.91 \\
-4.04 \\
-4.87 \\
-5.12\end{array}$ & 5.4 & $\begin{array}{l}-12.9 \\
-13.3\end{array}$ & 5. 3 & -13.9 & 5. 7 & -7.8 & 5.4 & -6.06 & 4.9 & $\begin{array}{l}-6.50 \\
-6.58 \\
-6.70 \\
-6.38 \\
-6.06 \\
-\end{array}$ & $\begin{array}{l}4.8 \\
4.9\end{array}$ & $\begin{array}{l}-2.81 \\
-3.48 \\
-3.63 \\
-4.06 \\
-5.88 \\
---.-\end{array}$ & $\begin{array}{r}5.2 \\
4.9\end{array}$ \\
\hline
\end{tabular}


rotations of salts of weak bases in general vary according to concentration, time, and temperature in manner analogous to that disclosed for the lead salts, and possibly some of the numerous discrepancies in the specific rotations of the various salts, recorded in the literature, may be due to these factors.

\section{EXPERIMENTAL PROCEDURE}

\section{ADDITION OF LEAD NITRATE TO CALCIUM GLUCONATE}

The optical rotation of a solution of calcium gluconate (saturated at $20^{\circ} \mathrm{C}$ ) was measured in a $4-\mathrm{dm}$ tube on a Bates saccharimeter and recorded in table 1 as the "rotation before adding lead nitrate." To $100 \mathrm{ml}$ of this solution $2 \mathrm{~g}$ of chemically pure crystalline lead nitrate was added and optical rotation measurements made at $20^{\circ} \mathrm{C}$. Each reading given in table 1 is the average of several on both sides of the recorded time. The results show that lead gluconate is formed very rapidly; that is, before the first readings could be made. The results given in figure 1 were obtained by similar experiments in which the amount of lead nitrate was varied. Only the initial rotations are reported, as the variation with time is essentially the same for each sample.

The measurements reported in table 2 were made with a saccharimeter, using the conversion factor 0.3462 . The samples of calcium gluconate, galactonate, mannonate, and altronate were heated slightly in order to bring the salt into solution. Heat was not applied to bring the lead salts into solution because heating causes changes in their optical rotations. Low concentrations of lead galactonate and arabonate were used on account of their low solubility.

The effect of adding lead nitrate to the various salts given in table 3 was determined essentially as described for the experiments given in table 1. In each case two solutions were prepared and read as soon as a clear solution was obtained. Pure crystalline salts were used with the exception of calcium $\beta$-glucoheptonate, calcium lactobionate, calcium rhamnonate, and calcium $l$-allonate; these were prepared by digesting the corresponding lactones with an excess of calcium carbonate. The concentration of salt was estimated from the amount of calcium in solution after removing the excess calcium carbonate by filtration.

\section{TITRATION OF LEAD GLUCONATE WITH BARIUM HYDROXIDE}

Samples of lead gluconate containing $1.4934 \mathrm{~g}$ in $50 \mathrm{ml}$ of water were placed in $100-\mathrm{ml}$ flasks containing sufficient standard barium hydroxide to give the desired concentrations. The quantities of barium hydroxide added are represented by the points on the curve in figure 2. After diluting the solutions to $100 \mathrm{ml}$ with freshly boiled distilled water, the $\mathrm{pH}$ was determined electrometrically with a quinhydrone electrode and checked by colorimetric measurements. At about pH 7 a precipitate of basic lead gluconate begins to form. On adding more alkali it dissolves, giving a clear solution at about $\mathrm{pH} 10$. This requires about 1.8 equivalents of alkali. 


\section{MUTAROTATION OF THE LEAD ALDONATES AND THE EFFECT OF HEAT TREATMENT}

Six grams of finely powdered lead gluconate, mannonate, galactonate, arabonate, or xylonate was added to $150 \mathrm{ml}$ of water at $20^{\circ} \mathrm{C}$. After shaking 10 minutes the excess lead salt was separated by filtration. The optical rotations and $\mathrm{pH}$ measurements recorded in table 4 in the columns headed "Freshly prepared sample" were obtained with the resulting filtrate; time was measured from the beginning of the filtration. After completing the measurements the unused portion of the solution was placed in a glass tube and heated in a boiling water bath for 10 minutes. Then it was cooled rapidly to $20^{\circ} \mathrm{C}$ and the measurements recorded under the "Heated sample" were made, for which time was taken from the moment when the tube was removed from the boiling water bath.

The optical rotations were converted to specific rotations in the usual manner. The concentration of the salt was calculated from the amount of lead in solution, which was determined by precipitation as lead chromate. The values for the concentrations represent the initial solubilities of the salts in water at $20^{\circ} \mathrm{C}$.

\section{LEAD GLUCONATE, $\mathrm{Pb}\left(\mathrm{C}_{6} \mathrm{H}_{11} \mathrm{O}_{7}\right)_{2}$}

Lead gluconate was made from gluconic acid and lead carbonate essentially as prepared by May, Weisberg, and Herrick. ${ }^{9}$ At $20^{\circ} \mathrm{C}$ about $3.1 \mathrm{~g}$ of the salt dissolved in $100 \mathrm{ml}$ of water in 10 minutes; on standing slightly more salt dissolved. The specific rotation $(-5.2)$ of the freshly prepared aqueous solution, containing $3.123 \mathrm{~g}$ of lead gluconate per $100 \mathrm{ml}$, was slightly less than that found by May, Weisberg, and Herrick $(-7.2)$, but as noted in this paper, different values are obtained by using different concentrations and experimental conditions. Analysis: Calculated for $\mathrm{Pb}\left(\mathrm{C}_{6} \mathrm{H}_{11} \mathrm{O}_{7}\right)_{2}$ : $\mathrm{Pb}, 34.69$. Found: $\mathrm{Pb}, 34.72$.

Basic lead gluconate, $\mathrm{Pb}\left(\mathrm{CaH}_{11} \mathrm{O}_{7}\right)_{2} \cdot 3 \mathrm{PbO} \cdot \mathrm{H}_{2} \mathrm{O}$, was obtained by adding $125 \mathrm{ml}$ of $N / 10 \mathrm{Ba}(\mathrm{OH})_{2}$ to $100 \mathrm{ml}$ of $N / 10$ lead gluconate. The resulting precipitate was separated by filtration, washed with water, and dried to constant weight at $60^{\circ} \mathrm{C}$ in vacuo. Analysis: Calculated for $\mathrm{Pb}\left(\mathrm{C}_{6} \mathrm{H}_{11} \mathrm{O}_{7}\right)_{2} .3 \mathrm{PbO} . \mathrm{H}_{2} \mathrm{O}: \mathrm{Pb}, 64.50$ Found: $\mathrm{Pb}, 64.55$.

\section{LEAD XYLONATE, $\mathrm{Pb}\left(\mathrm{C}_{5} \mathrm{H}_{9} \mathrm{O}_{6}\right)_{2} \cdot \mathrm{H}_{2} \mathrm{O}$}

Lead xylonate was prepared first by the method of Hasenfratz.10 Larger quantities were then prepared from barium xylonate obtained by oxidizing xylose electrolytically in the presence of barium carbonnate and barium bromide essentially as described ${ }^{11}$ for the preparation of calcium xylonate. The barium in the electrolyzed solution was removed by an equivalent quantity of sulphuric acid and the resulting hydrobromic and xylonic acids were neutralized with normal lead carbonate. After separating the insoluble lead bromide from the more soluble lead xylonate the solution was concentrated and seeded with lead xylonate. After standing several hours a good yield of the lead salt was obtained.

9 May, Weisberg, and Herrick. J. Wash. Acad. Sci., 19, 445 (1929).

10 Compt. Rend. 196, 350 (1933).

11 Isbell and Frush, BS J, Research 6, 1145 (1931) RP328. 
Lead xylonate crystallizes so readily that it may be prepared also by adding lead nitrate $(20 \mathrm{~g}$ in $50 \mathrm{ml}$ of water) to a concentrated solution of magnesium xylonate $(25 \mathrm{~g}$ in $50 \mathrm{ml}$ of water) followed by alcohol until the solution becomes slightly turbid. After seeding, about $15 \mathrm{~g}$ of crystalline lead xylonate can be separated. The product recrystallized from hot water gives, in 2 percent aqueous solution, $[\alpha]_{\mathrm{D}}^{20}=-6.8^{\circ}$, in agreement with the value reported by Hasenfratz; but the optical rotation varies with concentration and changes slightly when the solution is heated or allowed to stand.

Aqueous solutions of lead xylonate react definitely acid and combine with bases in much the same manner as lead gluconate. A precipitate of basic lead xylonate corresponding to the formula, $\mathrm{Pb}\left(\mathrm{C}_{5} \mathrm{H}_{9} \mathrm{O}_{6}\right)_{2} .3 \mathrm{PbO} . \mathrm{H}_{2} \mathrm{O}$, is obtained when lead xylonate is treated with slightly more than one equivalent of dilute barium hydroxide. The basic salt dissolves in an excess of alkali or in the presence of considerable calcium or magnesium xylonate.

\section{LEAD GALACTONATE, $\mathrm{Pb}\left(\mathrm{C}_{6} \mathrm{H}_{11} \mathrm{O}_{7}\right)_{2}$}

Although the properties of lead galactonate are not recorded in the literature, it is easily prepared and should find value for separating galactonic acid for analytical or for preparatory purposes. It may be obtained by neutralizing galactonic acid with lead carbonate or by treating calcium galactonate with lead nitrate. About $15 \mathrm{~g}$ of calcium galactonate is dissolved in $100 \mathrm{ml}$ of hot water, and $15 \mathrm{~g}$ of lead nitrate added; after cooling to $0^{\circ} \mathrm{C}$, about $15 \mathrm{~g}$ of crystalline lead galactonate separates. After recrystallization from water and airdrying, the product corresponds to the formula, $\mathrm{Pb}\left(\mathrm{C}_{6} \mathrm{H}_{11} \mathrm{O}_{7}\right)_{2}$. Analysis calculated for $\mathrm{Pb}\left(\mathrm{C}_{6} \mathrm{H}_{11} \mathrm{O}_{7}\right)_{2}: \mathrm{Pb}, 34.69$. Found: $\mathrm{Pb}, 34.78$.

The salt resembles lead gluconate in that it reacts definitely acid and on treatment with slightly more than one equivalent of barium hydroxide gives a basic lead galactonate. The freshly precipitated basic lead salt is so fine that it is difficult to separate by filtration. For analysis the product was separated by centrifuging, washed with water, and dried at $60^{\circ} \mathrm{C}$ in vacuo. Analysis calculated for $\mathrm{Pb}\left(\mathrm{C}_{6} \mathrm{H}_{11} \mathrm{O}_{7}\right)_{2} .3 \mathrm{PbO} \cdot \mathrm{H}_{2} \mathrm{O}: \mathrm{Pb}, 64.50$. Found: $\mathrm{Pb}, 64.73$. The salt contains less lead than the salt, ${ }^{12} \mathrm{~Pb}\left(\mathrm{C}_{6} \mathrm{H}_{11} \mathrm{O}_{7}\right)_{2} .4 \mathrm{PbO}$, obtained by precipitation of galactonic acid with basic lead acetate.

\section{LEAD ARABONATE, $\mathrm{Pb}\left(\mathrm{C}_{5} \mathrm{H}_{9} \mathrm{O}_{6}\right)_{2}$}

Lead arabonate is difficultly soluble and easily prepared either from arabonic acid or from calcium arabonate. Analysis calculated for $\mathrm{Pb}\left(\mathrm{C}_{5} \mathrm{H}_{9} \mathrm{O}_{7}\right)_{2}: \mathrm{Pb}, 38.56$. Found: $\mathrm{Pb}, 38.59$. The new salt exhibits the acidic properties mentioned for the other lead aldonates and in slightly alkaline solution gives a difficultly soluble basic salt which has not been analyzed.

\section{LEAD MANNONATE, $\mathrm{Pb}\left(\mathrm{C}_{6} \mathrm{H}_{11} \mathrm{O}_{7}\right)_{2}$}

Lead mannonate was obtained by treating calcium mannonate with an equivalent quantity of oxalic acid, neutralizing the acid set free with lead carbonate, and letting the filtered solution evaporate spontaneously. It separates in slender crystals which frequently

\footnotetext{
${ }_{12}$ Beilstein's Handbuch der Organischen Chemie, Aufl. 4, 3, 191.
} 
appear needlelike. The air-dried sample contains 34.69 percent of lead which corresponds to the formula, $\mathrm{Pb}\left(\mathrm{C}_{6} \mathrm{H}_{11} \mathrm{O}_{7}\right)_{2}$. The new salt exhibits the acidic properties noted for lead gluconate and in slightly alkaline solution gives a difficultly soluble basic salt.

\section{CALCIUM XYLONATE, $\mathrm{Ca}\left(\mathrm{C}_{5} \mathrm{H}_{9} \mathrm{O}_{6}\right)_{2} \cdot 2 \mathrm{H}_{2} \mathrm{O}$}

After many attempts during the past 5 years crystalline calcium xylonate was finally obtained from an aqueous solution of calcium xylonate prepared from xylonic $\gamma$-lactone and calcium carbonate. The crystals grow slowly in impure solutions but readily when pure. Previously Nef ${ }^{13}$ reported that the product he obtained by precipitation of crude calcium xylonate with alcohol was crystalline, but he did not describe it in sufficient detail for the writer to identify it with the above-described product. The crystals, which are slender and pointed like dagger blades, may be separated by filtration and readily purified. When seed is available the substance can be prepared from basic calcium xylonate, or from the product resulting from the electrolytic oxidation of xylose, as described by Isbell and Frush. ${ }^{14}$ For analysis the salt was recrystallized from hot water, collected on a filter, washed with aqueous alcohol, and dried in air at room temperature. Analysis calculated for $\mathrm{Ca}\left(\mathrm{C}_{5} \mathrm{H}_{9} \mathrm{O}_{6}\right)_{2} .2 \mathrm{H}_{2} \mathrm{O}: \mathrm{C}, 29.54$; H, 5.46; Ca, 9.86. Found: C, 29.71; H, 5.47; Ca, 9.92. At $20^{\circ} \mathrm{C}$ $27.7 \mathrm{~g}$ of the salt dissolves in $100 \mathrm{~g}$ of water. The specific rotation varies slightly with concentration in aqueous solutions containing less than $5 \mathrm{~g}$ per $100 \mathrm{ml}$. $[\alpha]_{\mathrm{D}}^{20}=+13.5-.53 c$, where $c$ is the number of grams of the salt in $100 \mathrm{ml}$.

\section{CALCIUM $a$-GLUCOHEPTONATE, $\mathrm{Ca}\left(\mathrm{C}_{7} \mathrm{H}_{13} \mathrm{O}_{8}\right)_{2} \cdot 3 \mathrm{H}_{2} \mathrm{O}$}

Calcium $\alpha$-glucoheptonate was obtained in the crystalline state, probably for the first time. The first crystals were prepared by evaporating an aqueous solution of calcium $\alpha$-glucoheptonate obtained from $\alpha$-glucoheptonic lactone and calcium carbonate. It can be recrystallized from water, but on account of its high solubility (60 g in $100 \mathrm{~g}$ of water at $20^{\circ} \mathrm{C}$ ) warm aqueous alcohol is preferable. At room temperature it separates in needlelike crystals which are not suitable for its purification, but at higher temperatures wider and thicker crystals are obtained which can be separated readily from the mother liquor. The product used for analysis was recrystallized from aqueous alcohol at about $50^{\circ} \mathrm{C}$ and dried at room temperature in air. Analysis calculated for $\mathrm{Ca}\left(\mathrm{C}_{7} \mathrm{H}_{13} \mathrm{O}_{8}\right)_{2} .3 \mathrm{H}_{2} \mathrm{O}$ : C, 30.86; $\mathrm{H}$, 5.93; Ca, 7.36. Found: C, 30.93; H, 5.95; Ca, 7.48. On drying at $100^{\circ} \mathrm{C}$ in vacuo the loss in weight was 9.96 percent; the sample darkened slightly. In 2.7-percent aqueous solution the hydrated salt gives $[\alpha]_{\mathrm{D}}^{20}=+5.95$.

Washington, January 22, 1935.

13 Liebigs Ann. Chem. 403, 252 (1914).

14 BS J. Research 6, 1145 (1931) RP328; and 14, 359 (1935) RP773. 